\title{
Treacle Protein
}

National Cancer Institute

\section{Source}

National Cancer Institute. Treacle Protein. NCI Thesaurus. Code C75599.

Treacle protein $(1488 \mathrm{aa}, \sim 152 \mathrm{kDa}$ ) is encoded by the human TCOF1 gene. This protein plays a role in skeletal development. 